\title{
DOES INFRASTRUCTURE REFORM WORK FOR THE POOR? A CASE STUDY ON THE CITIES OF LA PAZ AND EL ALTO IN BOLIVIA $^{1}$
}

\author{
VIVIEN FOSTER ${ }^{2}$ AND OSVALDO IRUSTA ${ }^{3}$
}

World Bank Policy Research Working Paper 3177, December 2003

The Policy Research Working Paper Series disseminates the findings of work in progress to encourage the exchange of ideas about development issues. An objective of the series is to get the findings out quickly, even if the presentations are less than fully polished. The papers carry the names of the authors and should be cited accordingly. The findings, interpretations, and conclusions expressed in this paper are entirely those of the authors. They do not necessarily represent the view of the World Bank, its Executive Directors, or the countries they represent. Policy Research Working Papers are available online at http://econ.worldbank.org.

\footnotetext{
${ }^{1}$ This research was originally prepared as a background paper for the Public Private Infrastructure Advisory Facility Country Framework Report for Bolivia.

${ }^{2}$ Vivien Foster is an Economist in the Office of the Director for Finance, Private Sector and Infrastructure in the Latin America and Caribbean Region of the World Bank.

${ }^{3}$ Osvaldo Irusta is a graduate student at the Universidad Católica de Bolivia and Adviser to the Superintendent of Electricity in Bolivia.
} 


\section{Acknowledgements}

The authors are grateful to the Public Private Infrastructure Advisory Facility for financing this research which was produced as a background paper for the Bolivia Country Framework Report.

The authors would also like to acknowledge the helpful guidance and comments of the project manager Jose Luis Guasch and coordinators Steve Ettinger and Dana Rysankova. Any remaining errors are our own responsibility.

The following people played the invaluable role of providing background information and data for the study: Mónica Ayala (SISAB); Franco Bertone (ENTEL); Ismael Carrasco (SITTEL); Alain Carbonnel (Aguas del Illimani); Fresia Guzmán (Consultant); José Morales (SITTEL); Rolando Morales (CIESS-Econométrica SRL); Bernardo Tribeño (Telecel); Miguel Urquiola (Universidad Catolica de Bolivia); Mauricio Valdez (Electropaz); and the Federación de Juntas Vecinales. 


\section{Executive Summary}

From 1994 onwards, Bolivia undertook a major reform of its infrastructure sectors. This paper examines the impact of the reforms from the perspective of poor households in the adjacent cities of La Paz and El Alto. The reform process affected each of the three main utilities serving these cities in very different ways. In the case of water, operating responsibilities were transferred from the public to the private sector. In the case of telephony, local service continued to be provided by a cooperative, but with increasing competition from cellular providers. In the case of electricity, service provision remained in the hands of a private company. However, the common feature of the reforms across all of these sectors was the signature of a concession contract between the utility and the regulatory agency, which made all three service providers increasingly accountable for their actions.

Whereas the electricity and telephone companies were required to meet a generic Universal Service Obligation, the water utility was placed under much more stringent obligations to meet specific connection targets in low income neighborhoods. These differences of contractual design show-up in the rate of new connections after the reform. Following a temporary increase to deal with accumulated requests, the rate of new connections to the electricity and fixed line telephone services fell back to pre-reform levels. By contrast, the number of new water (and sewerage) connections each year increased substantially from 10,000 (and $6,000)$ per year in the pre-reform period $(1993 / 6)$ to 17,000 (and 10,000) per year in the post-reform period (1997/9).

Furthermore, the connections policy of the water utility was relatively favorable to low income customers, with the possibilities of (a) spreading the payment of the US\$100 to US\$180 connection charges over a two year period, and (b) opting for a lower cost alternative (known as a 'condominial' connection) which allows households to reduce connection charges by $20 \%-40 \%$ if they are prepared to contribute their own labor to the network extension process. Although water tariffs increased by an average of $20 \%$ at the time of the reform, simultaneous reforms in the tariff structure have meant that those consuming less 7.0 cubic meters per month are better off; average water consumption in El Alto is only 5.9 cubic meters per month.

In contrast, the telephone cooperative charges a US\$1,500 membership fee in order to obtain a fixed telephone line; a sum that is well beyond the reach of all but the richest households. At the request of the government, the cooperative introduced a lower US\$120 connection fee for non-members payable in installments over two and a half years. However, given that non-members are required to pay a rental fee of \$23 per month (versus US\$1 per month for cooperative members), this policy has done little to improve the accessibility of fixed line services to the poor.

Interestingly, it is the introduction of competition in the cellular telephone market (which was not subject to any social policy requirements) that has done most to broaden social access to telecommunications. As a result of competition: (a) the costs of obtaining a cellular telephone and line fell from several hundred dollars to around US\$60; (b) calling party payment charges were abolished reducing the effective cost of using a cellular telephone by $68 \%$; and (c) prepayment cards were introduced making it possible to keep running costs down to minimal levels. As a result, there were 66,000 new cellular subscribers each year between 1996/99 which represents a tenfold increase in cellular penetration, with the vast majority of these new subscribers using prepayment cards. There are now 40\% more cellular lines than fixed lines in La Paz and El

Alto; an outcome that is likely to be technologically inefficient in a high density urban area, but which reflects the distortions caused by the pricing policy for fixed line services.

There is a variety of evidence to show that these improvements in access to services did not bypass the poor. Official survey data shows that households in the first income quintile saw barely any improvement in access to utility services in the period leading up to the reforms 1989/94. Between 1994/99, however, the coverage rates for these households rose by more than 20 percentage points for water and sewerage, and more than 10 
percentage points for electricity and telephones. This concurs with geographical evidence from utility databases indicates that $80 \%$ of new water and sewerage connections and $65 \%$ of new electricity and telephone connections went to residents in the poorest neighborhoods of La Paz and El Alto. 


\section{Introduction}

From 1994 onwards, Bolivia underwent a major reform of its infrastructure sector, which included creation of regulatory frameworks, issuing of concession contracts, liberalization of markets, and a novel form of private sector participation that became known as 'capitalization'. The scope of the reform varied considerably across sectors, ranging from wholesale privatization and liberalization of the electricity and telecommunications sectors, to more limited regulatory reform in the water sector reforms, with the only enduring case of private sector participation being a concession contract for the cities of La Paz and El Alto. A common element of the reform across sectors was the creation of a multi-sector regulatory framework through the SIRESE Law of 1994, which resulted in the creation of a number of sectoral Superintendencies to oversee the performance of the infrastructure sectors.

The primary objectives of these reforms were to reduce state subsidies to the infrastructure sector, attract private capital and improve overall sector efficiency. With the partial exception of the water and sewerage sector, the improvement of equity in access to basic services was not a central objective of the reform program at the time it was being implemented. However, the recent economic slowdown in Bolivia combined with growing social unrest, has led people to question to what extent such reforms had any beneficial impact on the poor.

There are a number of reasons to believe that the reform could have benefited the poor. For one thing, the new influx of private capital combined with sharpened commercial incentives at least created the possibility of financing network expansions into previously unserved communities. At the same time, the shift towards competition in some services and incentive-based price regulation in others, promised lower prices making services more affordable to poor households.

On the other hand, there are also reasons to think that the benefits of reform could have largely bypassed poorer communities. Private operators driven by profit considerations tend to concentrate efforts on the most lucrative segments of the market, and would not necessarily have found it commercially attractive to go into low income neighborhoods. Furthermore, the absence of focus on poverty issues at the time of the reform, meant that these were not always explicitly designed in such a way as to overcome such adverse incentives and ensure that the needs of the poor were taken into account.

The purpose of this paper is to provide some concrete empirical analysis of how the reforms affected poor urban households in Bolivia. The methodology adopted will be that of a case study of the cities of La Paz and El Alto. These cities were chosen for a number of reasons. First, they represent the single largest conurbation in Bolivia accounting for a third of the total urban population and just over a third of the urban poor. Second, they present a wide range of socio-economic circumstances and a relatively clear geographic segmentation of poverty. Third, they are the only cities that experienced enduring reform 
in the water and sewerage sector in addition to the electricity and telecommunications sectors.

The analysis presented here complements a recent study by Barja and Urquiola (2001), which undertakes a national level assessment of this same question recently based largely on household survey analysis. It does so by analyzing in greater detail the contractual obligations of the utilities, the incentives these created and the ways in which their tariff reforms affected the affordability of services for the poor.

\section{The Case Study Context}

The reform process dramatically affected all three of the utilities providing electricity, telephone and water services to the households of La Paz and El Alto. In all three sectors, the centerpiece of the reform was the signature of a concession contract between the respective regulatory agency and the utility company. For the first time, these concession contracts provided the basis for regulatory control of the utilities. They incorporated a number of very significant changes relating to service expansion targets, quality of service parameters, and tariff policies.

In the water and sewerage sector, the concession contract was also used as a vehicle to introduce private sector participation, transferring responsibility for the service from the municipal company SAMAPA to the private operator AISA for a period of 30 years. However, there was no such change in the management or ownership of the electricity and telecommunications companies. The new electric utility-Electropaz — was created when the electric utility COBEE divested of its distribution assets in response to the 1994 Electricity Law which prohibited vertical integration. While the local telephone service continued to be run by the cooperative COTEL. COTEL has begun to face limited competition from cellular telephones following the licensing of Telecel in 1990 as the first cellular provider. This competition greatly intensified after 1995, when a second cellular license was granted to ENTEL.

Table 1.1: Cross-sectoral overview of reforms

\begin{tabular}{|l|l|l|l|}
\hline & Electricity & Telecommunications & Water and Sewerage \\
\hline Date of concession & January 1996 & July 1996 & July 1997 \\
Subsequent provider & COBEE (private sector) & $\begin{array}{l}\text { Clectropaz (private sector) } \\
\text { COTEL (cooperative) }\end{array}$ & $\begin{array}{l}\text { SAMAPA (municipal) } \\
\text { Nature of reform }\end{array}$ \\
$\begin{array}{l}\text { Rssuing of concession contract } \\
\text { Issuing of concession contract for } \\
\text { fixed line service to COTEL and } \\
\text { second license for cellular services } \\
\text { to ENTEL in 1995 }\end{array}$ & $\begin{array}{l}\text { Private sector participation } \\
\text { via a concession contract }\end{array}$ \\
\hline
\end{tabular}

Source: Own elaboration,

The objective of this case study is to evaluate the impact of these reforms on poor households in La Paz and El Alto. The incidence of poverty in both cities is high (Table 1.2). Some $60 \%$ of the inhabitants of El Alto and $50 \%$ of residents of La Paz live on less than $\$ 1.40$ per capita per day. While about $40 \%$ of people in El Alto and $30 \%$ of people 
in La Paz live on less than $\$ 0.90$ per capita per day. Poverty rates are significantly higher in El Alto than La Paz, due to geographical segmentation of poverty. Moreover, within La Paz, poverty tends to be concentrated in the northern neighborhoods and 'laderas' or steep cliffs surrounding the city.

Table 1.2: Poverty statistics

\begin{tabular}{|l|c|c|}
\hline & Extreme Poverty & General Poverty \\
\hline Poverty lines (US\$ pc pm) & 26.05 & 42.92 \\
Headcount poverty rates (\%) & 41.16 & \\
- El Alto & 27.53 & 59.47 \\
- La Paz & & 48.37 \\
\hline
\end{tabular}

Source: Encuesta Nacional de Hogares, 1999

Access to utility services makes an important contribution to the welfare of poor households. Indeed, household survey evidence indicates that the poorest $20 \%$ of urban households in Bolivia are willing to pay significant rental premia to live in dwellings that have utility connections. These premia are equivalent to $12 \%$ of their income (or $\$ 93$ per year) for water, $2 \%$ of their income (or $\$ 21$ per year) for sewerage, and $2 \%$ of their income (or $\$ 19$ per year) for electricity (Estache et al., 2001).

Moreover, changes in utility tariffs can have a substantial impact on the budgets of poor households. Utility charges account for $10 \%$ of the expenditure of the poorest urban households in Bolivia (World Bank, 2001). About two thirds of this goes on electricity, and a further quarter on water and sewerage services (Figure 1.1). If these direct expenditures are added to the aforementioned rental premia, utility spending accounts for more than a quarter of the budget of the poorest households.

Figure 1.1: Utility expenditure shares by quintile

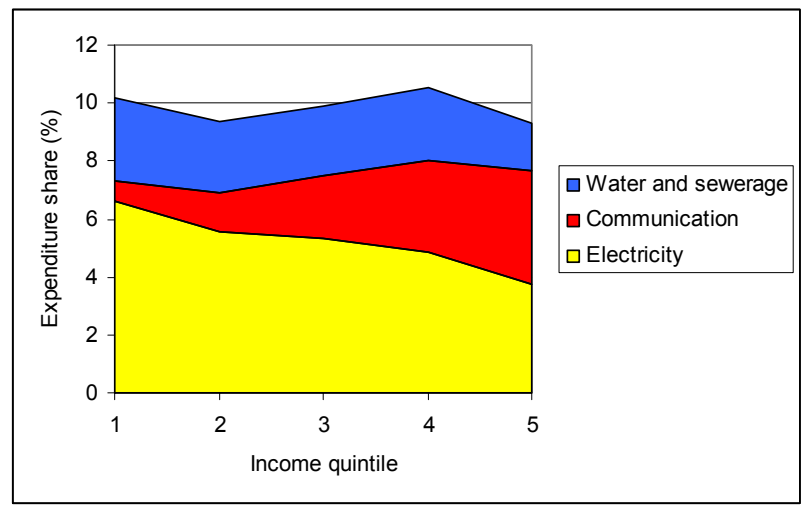

Figure 1.2: Direct expenditure versus rental premia for first quintile

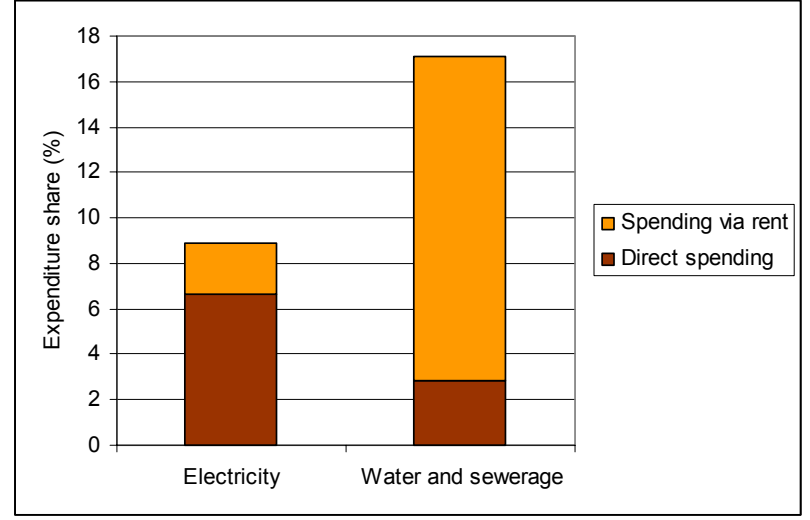




\section{Access to Service Connections}

\subsection{Expectations}

The concession contracts signed with the three incumbent utilities Electropaz, COTEL, and AISA differ markedly with respect to the obligations they place for the expansion of coverage (Table 3.1), as well as the affordability of new connections to low income households. This section analyzes the conditions created in each sector and predicts the anticipated outcome for service coverage.

Table 3.1: Cross-sectoral overview of service obligations

\begin{tabular}{|c|c|c|c|}
\hline & Electricity & Telecommunications & Water and Sewerage \\
\hline USO & $\begin{array}{l}\text { Service on request within } \\
\text { concession area. }\end{array}$ & $\begin{array}{l}\text { Service on request within concession area, } \\
\text { reducing waiting list as follows: } \\
\text { - 1997: meet backlog of } 12,000 \text { requests } \\
\text { - 1998: meet } 75 \% \text { of requests in } 12 \text { weeks } \\
\text { - 1999: meet } 85 \% \text { of requests in } 8 \text { weeks } \\
\text { - 2000: meet } 95 \% \text { of requests in } 15 \text { days. }\end{array}$ & $\begin{array}{l}\text { Service on request within } \\
\text { concession area. }\end{array}$ \\
\hline Exclusivity & No(?) & Yes (6 years), unless fail to meet USO. & Yes (30 years) \\
\hline Expansion & $\begin{array}{l}\text { Investment target: } \$ 26.7 \mathrm{~m} \text { in } \\
\text { distribution } 1997-2001 .\end{array}$ & $\begin{array}{l}\text { Output target: one public telephone per } 200 \\
\text { subscribers by } 2000 .\end{array}$ & $\begin{array}{l}\text { Output target: By } 2001 \text { : } \\
\text { - Water: } 71,752 \text { connections in } \\
\text { El Alto (or } 100 \% \text { coverage) } \\
\text { - Sewerage: } 27,200 \text { connections } \\
\text { in El Alto ( } 38,000 \text { overall) } \\
\\
\text { Various financial penalties exist } \\
\text { for failing to meet these targets. }\end{array}$ \\
\hline
\end{tabular}

Source: Concession contracts for Electropaz, COTEL and AISA

Electricity. Electropaz is - in effect - subject only to a standard Universal Service Obligation; since the company's investment targets relate to general distribution network expenditure with no specific link to connections. This makes service expansion entirely demand driven, and suggests that the affordability of the connection charge will be a key factor determining the extent to which poor households are able to obtain access. Electropaz levies a modest connection charge, which was increased from $\$ 1$ to $\$ 5$ following the Electricity Law. However, the main costs of connecting are those associated with the meter, meter box, and line from the house to grid. These costs must be covered by the household, and come to a total of around $\$ 150$.

The costs of an electricity connection are thus comparable to the charge for water and sewerage services. However, unlike water and sewerage, there is no provision for households to spread the payment over time in installments. Given that the connection costs are equivalent to three minimum wages, this could represent a significant hurdle to access for the poorest households. Electropaz reported that they recently investigated the possibility of providing a credit line for connection costs in association with a local micro-finance institution. Although there was considerable interest from the microfinance sector, it did not prove possible to implement such a scheme because Electropaz is not legally empowered to disconnect a customer for non-repayment of a loan to a third 
party institution, since the Electricity Law only allows disconnection for cumulative nonpayment of electricity bills. In the absence of any sanction for non-repayment, the microfinance institutions were unwilling to contemplate such a scheme.

Consumers in El Alto have been concerned about the level of electricity connection charges. Indeed, a local neighborhood association (FEJUVE) recently submitted an official complaint ('Documento de Pleito') to the electricity regulator. According to FEJUVE, connection costs could potentially be halved to $\$ 80$ if the consumer were at liberty to purchase and install his own meter and meter box on local markets rather than being forced to obtain imported equipment from Electropaz. However, Electropaz has questioned the quality and reliability of locally produced equipment. The issue is presently under consideration by the electricity regulator.

Figure 3.1: Connection charges by service

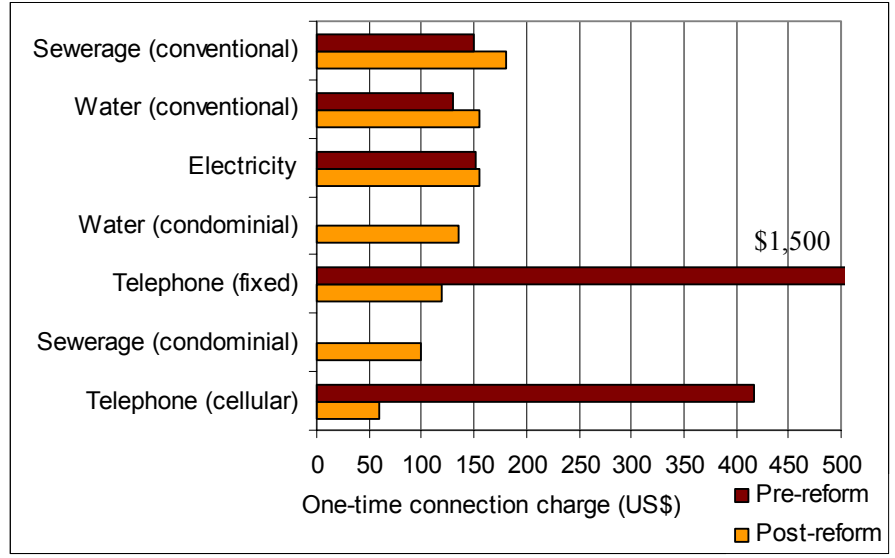

Sources: Electropaz, COTEL and AISA.

Figure 3.2: Minimum monthly connection payment by service relative to minimum wage

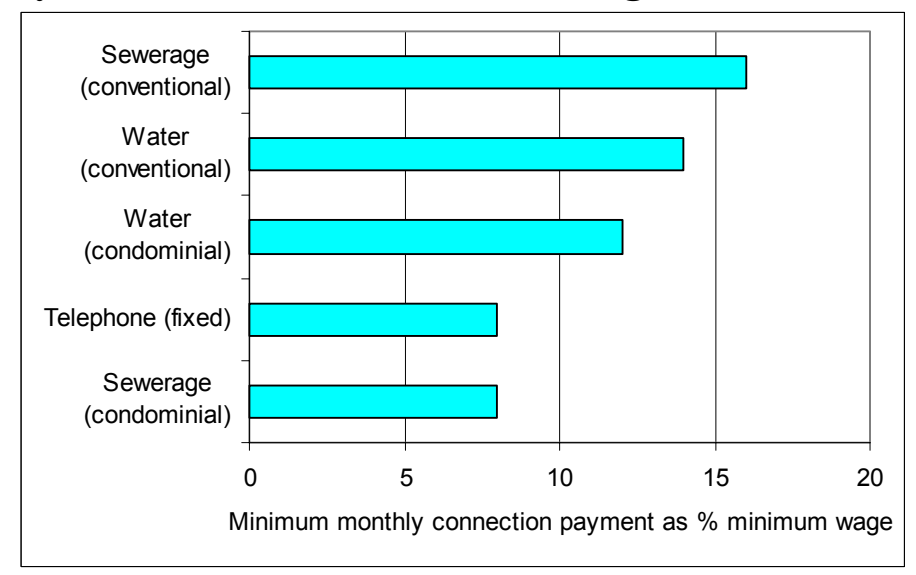

Sources: Electropaz, COTEL and AISA.

Water and sewerage. By far the most prescriptive service obligations are to be found in the water and sewerage sector. The reason is that raising service coverage to poor 
households, particularly in El Alto, was a clear and explicit political priority at the time when the concession contract was issued. Not only is AISA mandated to make a substantial number of new water $(72,000)$ and sewerage $(38,000)$ connections, but these must be made within a certain period of time and in defined locations, with significant financial penalties for failure to do so.

Although connection charges were allowed to increase by $20 \%$ at the time of the reform (Uzin, 1996), due to the focus on reaching low-income consumers considerable thought has been given to the issue of affordability. They are comparable in magnitude to those found for the electricity service. However, in contrast to electricity, the charges can be repaid over a two year period, keeping monthly contributions to around $10 \%$ of the minimum wage.

Perhaps the most significant innovation in the water and sewerage sector has been the willingness to adopt innovative approaches to network expansion which are designed to reduce the costs faced by low income households (Foster, forthcoming). In particular, a pilot project was set-up as a joint initiative between the Government of Bolivia, the Water and Sanitation Program and AISA to experiment with the use of condominial water and sewerage systems for 4,000 homes in El Alto. The condominial approach, which was pioneered in Brazil in the 1980s, uses an innovative engineering design that reduces the materials and labor requirements for network expansion, and involves community participation in the construction of the networks so that labor costs are further reduced. Cost savings of the order of $40 \%$ can be achieved using this method, although these are not perfectly reflected in the current differential of connection charges between conventional and condominial services.

Telephones. The form of the USO for COTEL is somewhat more stringent than Electropaz, in that the required speed of response to new service requests is explicitly specified and there is a substantial penalty for failing to meet contractual obligations; notably the loss of exclusivity. In addition, COTEL's concession contract specified output targets for the installation of public telephones.

Prior to the reform, the only way of obtaining a fixed telephone line was to join the cooperative, which entailed a membership fee of $\$ 1,500$. When the concession contract was signed, the regulator required COTEL to introduce an alternative connection scheme for non-members at the lower cost of $\$ 120$. Although, this represents a very substantial saving in connection costs, non-members face monthly fixed charges of $\$ 23$, as against a fixed charge of less than $\$ 1$ applied to cooperative members. This additional fixed charge of $\$ 22$ per month in perpetuity is equivalent to the $\$ 1,500$ membership fee at a discount rate of $18 \%$.

New customers are allowed to pay the $\$ 120$ connection charge in monthly installments over a 30 month period, which brings the monthly contribution down to $\$ 8$. However, COTEL has the right to demand $20 \%$ of the connection charge up-front as a deposit when a prospective customer is added to the waiting list; this represents a minimum charge of $\$ 24$ or about half of the monthly minimum wage. 
Notwithstanding, the lower connection charges this scheme has not been very effective in securing new customers. Only 3\% of new telephone customers since 1996 have chosen this option. In order to try and entice additional new customers in advance of market liberalization in November 2001, COTEL has recently introduced a special offer on the non-member connection, reducing the connection charge to $\$ 45$ and the monthly fixed charge to $\$ 15$.

Reforms in the cellular market probably had the greatest impact from an access perspective. Although Telecel had been licensed to provide mobile telephony since 1990, high connection charges of $\$ 417$, the high cost of the cellular telephone itself, and the practice of charging cellular subscribers for both in-coming and out-going calls, combined to keep the market relatively small. With the advent of competition in 1995 , connection charges dropped to $\$ 10$; a fraction of the price cap of $\$ 180$ for connection charges that had been set by the regulator. The list price of a cellular telephone has also come down to the range $\$ 150-\$ 300$, although between special offers and the thriving second hand market it is reportedly possible to obtain a device for as little as $\$ 50$. Hence, it is possible to obtain cellular service for as little as $\$ 60$, which is the lowest access cost across all of the utility services. However, this sum must be paid in one go as there is no provision for payment by installments.

Overall picture. In summary, the anticipated impact on access for the three sectors is very different reflecting the contrasting policies that were adopted in each case. In the case of electricity, the new concession contract does not appear to have introduced any changes that might be expected to accelerate the rate of access, since both connection charges and service obligations remained more or less unchanged.

In fixed line telephony, the concession contract could be expected to lead to a rapid improvement in the speed of access to fixed line services for those requesting it. At the same time, the introduction of a new connection charge at less than $10 \%$ of the cost of the cooperative membership fee could be expected to generate service requests from less affluent households who would previously have found it unaffordable, although the service charges associated with this type of connection remain very high. Of potentially greater significance in terms of access for the poor was the advent of competition in cellular telephony leading to declining access charges and more attractive payment plans.

Finally, in water and sewerage, higher coverage and more equitable patterns of access are effectively mandated by the targets built into the concession contract, and further facilitated by the introduction of the lower cost condominial option.

\subsection{Outcomes}

This section considers how patterns of access to basic services have changed in La Paz and El Alto since 1994, and evaluates to what extent this can be attributed to the reforms. It is not straightforward to establish the degree to which observed changes are attributable to the reform itself, or would have happened in any case due to technological progress or 
other changes in the economic environment. Two approaches can be taken to this problem. One is to compare trends in the years before and after reform; to the extent that pre-reform data can be found. The other is to compare trends geographically between areas with and without reform. In fact, this latter approach is only possible for water and sewerage, since electricity and telecommunications sector reform were nationwide. Finally, by comparing outcomes across sectors, it is possible to see to what extent the different approaches taken fed through into different consequences for service expansion.

Rate of new connections. A first key question is whether the rate of new connections to basic services increased noticeably as a result of the reform? Across all sectors there is a noticeable spike in the rate of new connections in the immediate aftermath of the reform (Figure 3.3). It seems likely that this spike relates to a catch-up effect as service providers cleared the backlog of unsatisfied service requests. However, in the case of electricity and fixed line telephony, this spike is short-lived and within about a year the rate of new connections reverts to its pre-reform levels. While for water and sewerage, the increase is sustained through to the present.

Figure 3.3: Rate of new connections

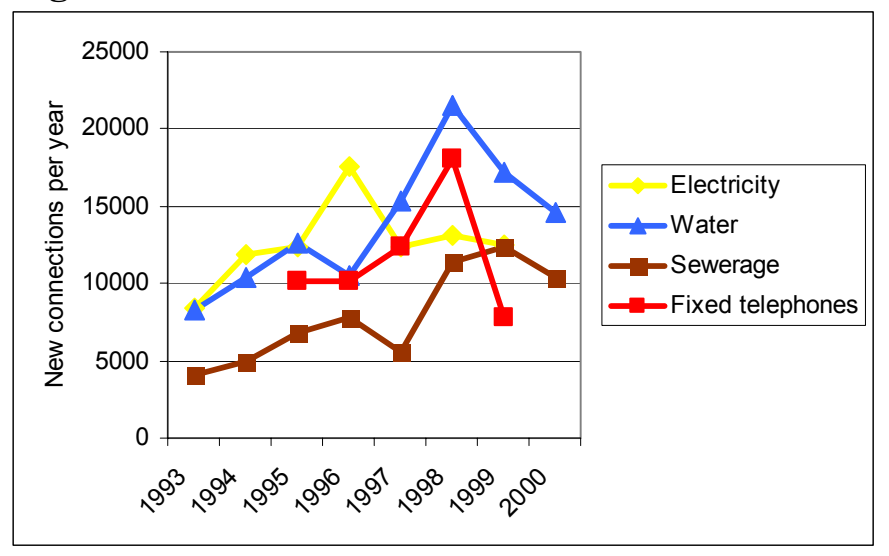

Sources: Electropaz, AISA and COTEL (2000).

Indeed, the annual rate at which new connections to both water and sewerage services increased by about $66 \%$ following the reform. Thus, the annual rate of new water connections rose from 10,469 during the period 1993-96 to 17,187 during the period 1997-99. While the annual rate of new sewerage connections rose from 5,906 during the period 1993-96 to 9,906 during the period 1997-99. Consequently, as of end 2000, AISA looks set to meet its connection targets for 2001. The growth in private household connections has been matched by a gradual closure of public standpipes, the number of which has declined by around a third in La Paz and over $80 \%$ in El Alto.

However, the rate of expansion of traditional household utility services of around 10,00020,000 connections per year, is dwarfed by comparison with what has been achieved in the mobile telephone market, which grew at an average annual rate of 66,583 new connections over the same period. Indeed, the total number of mobile telephone subscribers increased by a factor of 10 between 1996 and 1999, so that by the end of the 
decade there were $40 \%$ more mobile than fixed lines in La Paz and El Alto: a total of nearly 218,000 mobile subscribers versus 155,000 fixed line subscribers.

The introduction of pre-payment cards for cellular telephone in 1998 appears to have been a great stimulus to demand; indeed $86 \%$ of the increase in cellular penetration since 1997 took the form of prepaid telephones (Figure 3.4). Anecdotal evidence suggests that a significant proportion of these new clients are small entrepreneurs from the informal sector, although unfortunately there is no data to confirm this view ${ }^{4}$. By using prepaid telephones, these micro-entrepreneurs keep the running costs of the telephone to an absolute minimum but are still able to benefit from business-related in-coming calls.

Figure 3.4: Growth of mobile telephony

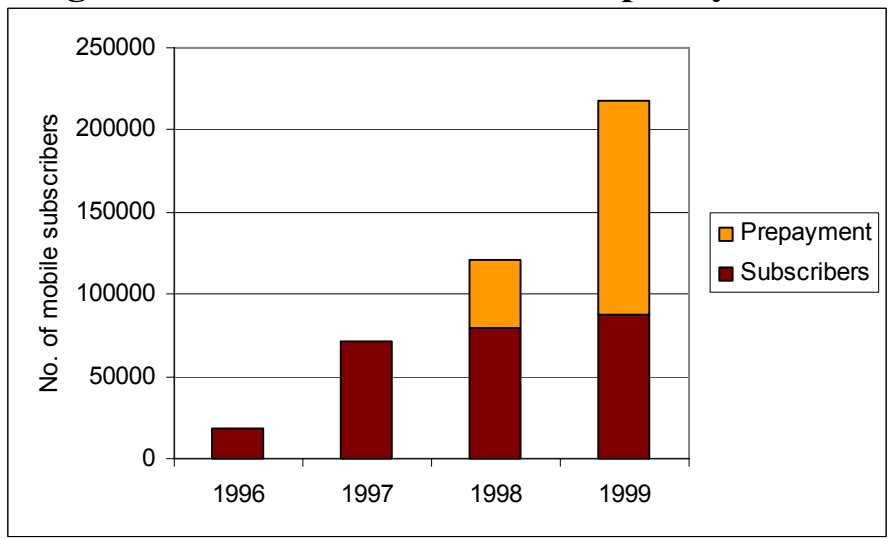

Sources: TELECEL and ENTEL (2000).

Both ENTEL and COTEL are licensed to provide public telephone service in La Paz and El Alto, although ENTEL telephone booths only provide long distance service. The number of public telephones in La Paz and El Alto increased by a factor of 10 over the same period (Figure 3.5). About three quarters of these telephones are operated by ENTEL. COTEL has only installed the minimum number of telephones required to meet its contractual obligation of one public telephone per 200 private lines.

\section{Figure 3.5: Growth of public telephones}

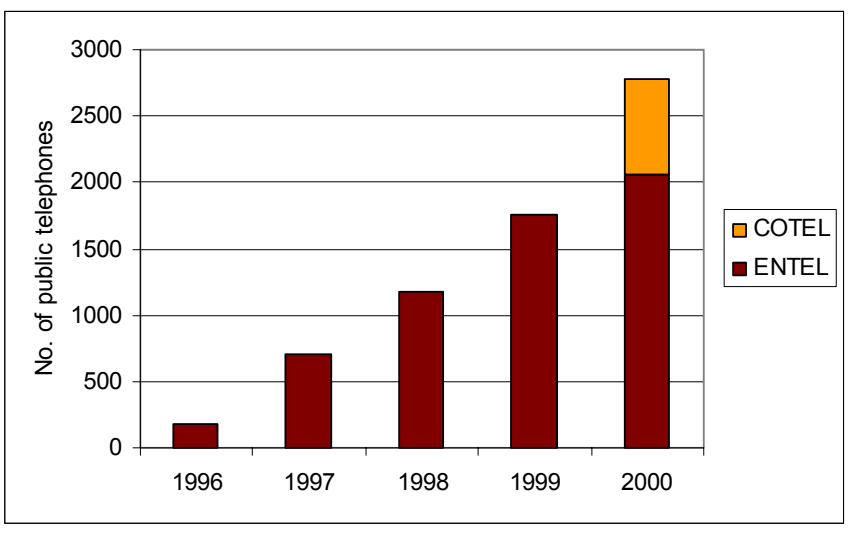

\footnotetext{
${ }^{4}$ Interview with Bernardo Tribeño, Gerente Económico, TELECEL, $13^{\text {th }}$ September 2000.
} 
However, aggregate statistics on the number of official public telephones do not really tell the full story about access in La Paz and El Alto ${ }^{5}$. On the one hand, public telephones are not always very accessible since in order to avoid vandalism telephones in outlying locations are often located inside retail outlets, and are therefore not available outside of normal retail hours.

On the other hand, the informal sector has effectively 'privatized' the public telephone service. First, many of the small street vendors or 'anaqueleros' have their own telephone lines (often coming straight out of the payment) which they rent out to the public for local calls at a fixed charge for a maximum three minute call. Indeed, the current telecommunications law explicitly allows for such small-scale resale of services. Second, vendors of public telephone coupons ${ }^{6}$ have been observed to padlock public telephone booths. This allows them to improve their sales by forcing any prospective callers to purchase coupons from them in return for securing access to the public telephone booth.

Impact on coverage. To what extent did the increase in new connections feed through into significant improvements in service coverage? A number of methodological considerations complicate the drawing of inferences about coverage rates from data on the number of household connections ${ }^{7}$. Hence, as a cross-check, the resulting coverage rates were compared with those reported in the Encuesta Continua de Hogares, 1999. Any major discrepancies are reported in the text. Notwithstanding, some uncertainty over the absolute level of connections, the results reveal interesting differences in the pattern of coverage trends between La Paz (Figure 3.6) and El Alto (Figure 3.7).

In the city of La Paz, progress in coverage of electricity, water and sewerage services has been modest since the reform. However, this reflects the fact that coverage was already close to universal for water and electricity. While the AISA concession contract, required

\footnotetext{
${ }^{5}$ Interview with Willy Garcia, Gerente Técnico, COTEL and Ismael Carrasco, Jefe de Servicios Básicos, SITTEL, 15th September 2000.

${ }^{6}$ A monopoly for the sale of these coupons has been given to registered blind people to provide them with a source of livelihood.

${ }^{7}$ There are two basic problems. The first, which affects all of the services, relates to the fact that the last Census took place in 1992, so that current population estimates are based on projections from a baseline that is nearly ten years old. The second problem arises when a single connection is shared by a number of households. This is particularly common in the water and sewerage sector where large apartment blocks are often served by a single meter. It may also arise in electricity and fixed line telephony, for example, when a number of families share a single house. It is therefore necessary to make assumptions about the number of inhabitants per connection. For water and sewerage, the calculations follow the practice adopted by AISA of assuming 12 inhabitants per connection in La Paz and 9 in El Alto, reflecting the greater prevalence of apartment buildings in La Paz. For electricity, the calculations follow the practice adopted by Electropaz of assuming 5 inhabitants per connection in La Paz and 6 in El Alto. In this case, the issue is not one of apartment buildings since each apartment typically has its own electricity meter. The differences between the two cities simply reflect beliefs about larger household size in El Alto. For fixed telephones, there is no convention of reporting household connection rates but rather number of lines per 100 inhabitants. In order to compute coverage statistics equivalent to those for the water and electricity sectors, the same assumptions about household size have been assumed as in the case of Electropaz.
} 
the company to put a major emphasis on sewerage expansion in El Alto, rather than La Paz. Nonetheless, it can be said that those coverage increases that did take place in $\mathrm{La}$ Paz almost certainly benefited poorer households. The reason is that the coverage rate for all three of these services is much higher than the proportion of non-poor households in the city (i.e. $60 \%$ ). This suggests that those households remaining uncovered are very likely to be poor households.

Telephony is the one service that has shown substantial coverage improvements in La Paz following sector reform. The gain in coverage appears to have been of the order of 15-20 percentage points. However, there are serious discrepancies between data sources as to the baseline level from which coverage increased. According to data from COTEL, fixed line telephone coverage in 1996 was already at the 50\% level. While, according to household survey data, fixed plus cellular telephone coverage at that time was only $30 \%$.

Figure 2.4: Evolution of coverage in La Paz

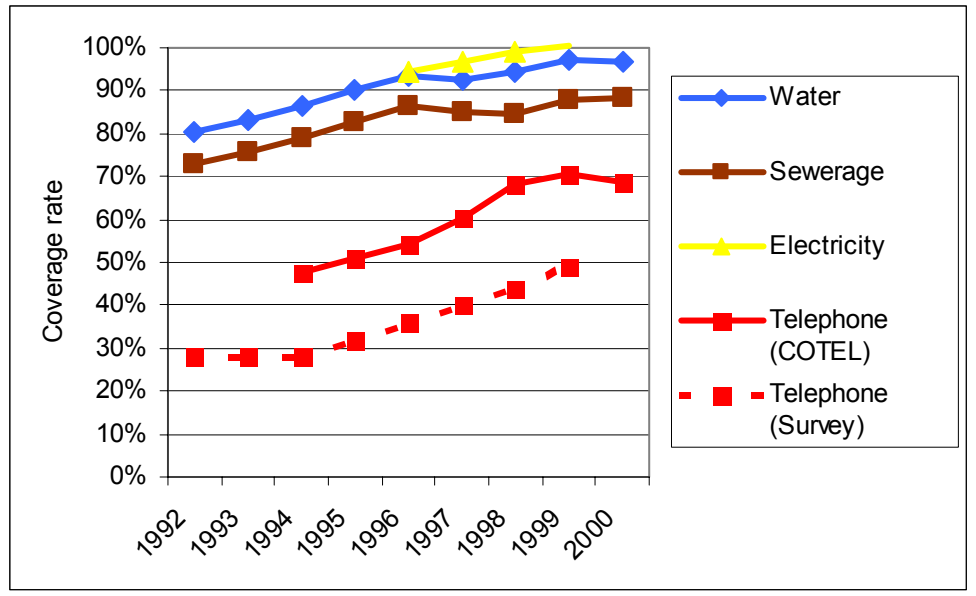

Sources: INE, Electropaz, AISA and COTEL, 2000

Figure 2.5: Evolution of coverage in El Alto

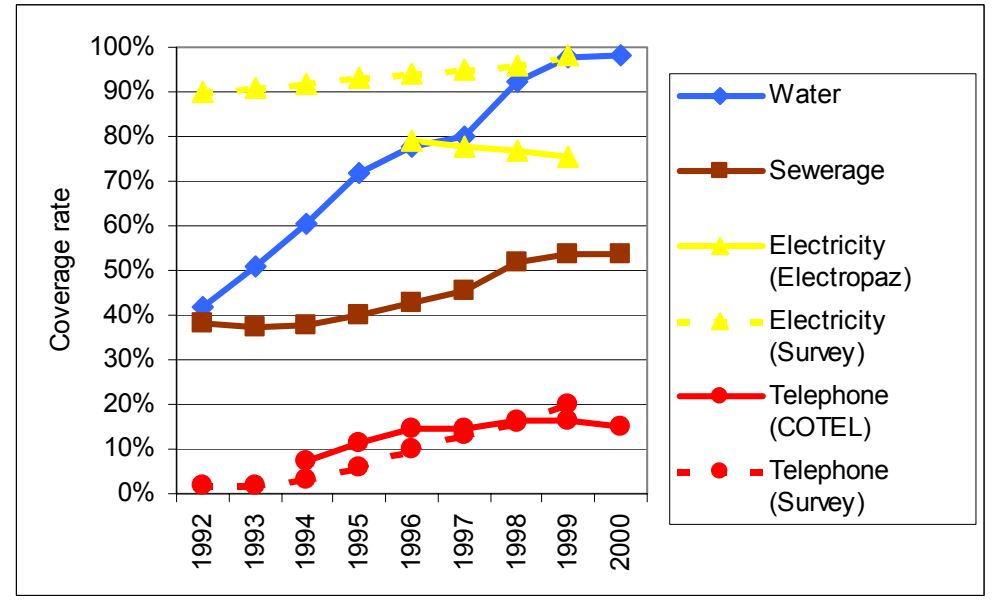

Sources: INE, Electropaz, AISA and COTEL, 2000 
In the city of El Alto, there have been substantial gains in access to water and sanitation services. The water coverage rate continued to grow at the same rapid rate as before the reform, gaining 20 percentage points in the period 1997-2000 and thereby attaining universal coverage. While sewerage coverage which had been more or less static at around $40 \%$ during the earlier part of the decade, increased by 10 percentage points to reach $53 \%$ by the year 2000 .

Comparison with other urban areas suggests that coverage increases for the water service in La Paz and El Alto were in fact comparable to those found elsewhere in the country where there was no private sector participation (Figure 2.6). However, with respect to the sewerage service, the coverage rate in $\mathrm{La} \mathrm{Paz}$ and $\mathrm{El}$ Alto rose by more than 15 percentage points between 1994-99, whereas coverage in other urban areas increased by less than 10 percentage points over the same period. (Barja and Urquiola, 2001)

Electricity coverage appears to have been more or less static following the reform, however there are significant discrepancies between data sources as to the overall level of coverage. According to Electropaz data, coverage in El Alto stands at around $75 \%$. However, according to survey data, coverage in El Alto is around $95 \%$. While such a difference could be explained in terms of illegal connections, Electropaz does not believe that this is a major problem in El Alto. One possible explanation is that households in El Alto that lack official connections are still able to obtain electricity by wiring-up to a neighbors system and purchasing electricity from them. In this case, the electricity is not being stolen from the network but merely purchased from an intermediary. Electropaz reports that the main obstacle to further expanding coverage in El Alto is the fact that new settlements cannot be legally connected until they have their urbanization plans approved by the municipality; a process that is often subject to lengthy delays.

Once again, there is some discrepancy between the telephone coverage estimates resulting from COTEL data and those derived from household surveys. The COTEL data shows that fixed line coverage has been stagnant at just under $20 \%$. While the household survey data indicates that coverage of fixed plus cellular telephones has increased by about 10 percentage points since the reform from a pre-reform base of around $10 \%$.

Figure 3.8: Geographical comparison of gains in water and sewerage coverage

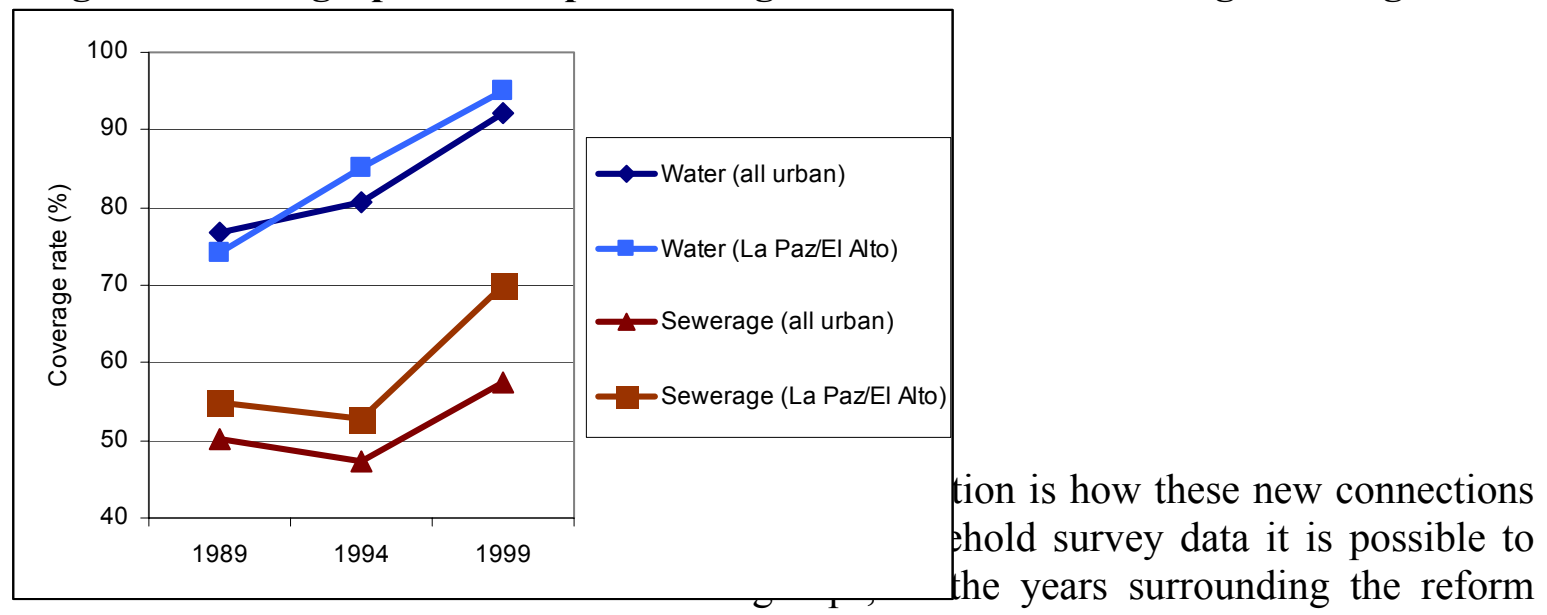


process $^{8}$. However, it is important to note that the samples underlying these surveys are designed to be representative at the department level rather than at the city level. Hence although, in the case of La Paz and El Alto, the population of these two cities represents two thirds of the population of the department; the results should nonetheless be taken as illustrative rather than entirely representative.

The impact on the poor can best be seen by focusing on access trends for the first quintile, which represent the poorest $20 \%$ of the population ${ }^{9}$. In the city of La Paz, the results show that there was little if any progress in coverage for the first quintile in water, sewerage or telephone services between 1989-94. Following 1994, however the access rates for all three of these services increased substantially by around 15 percentage points (Figure 3.9). It is particularly noteworthy that (fixed plus cellular) telephone coverage in the first quintile doubled from $12 \%$ to $24 \%$ between 1994 and 1999 . Only in the case of electricity — where in fact coverage has been close to universal since 1989-was there no discernible change in the rate of service expansion before and after the reforms.

Figure 3.9: Evolution of coverage for poorest quintile in La Paz

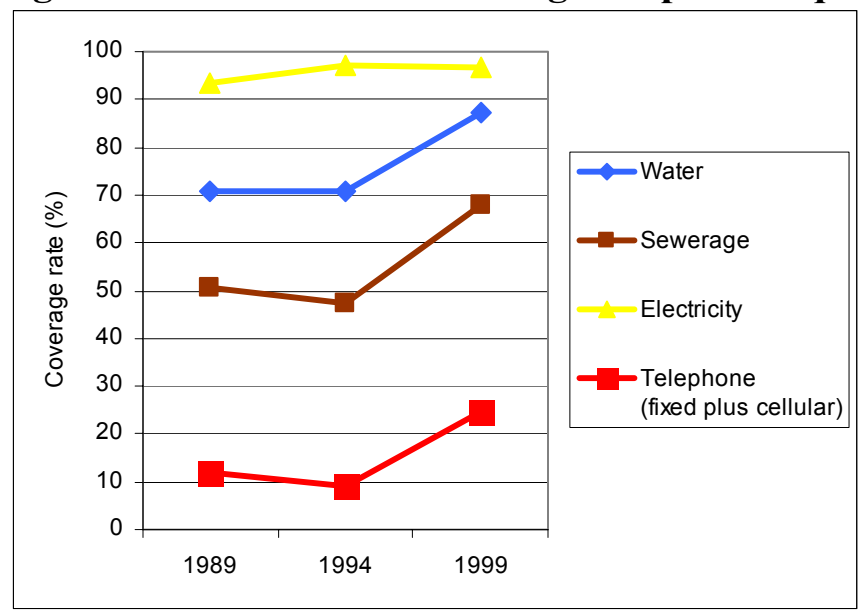

Sources: Encuesta Integrada de Hogares (1989, 1994); Encuesta Continua de Hogares (1999)

In El Alto, a similar pattern emerges except that - even for households in the same income bracket - coverage levels start from a lower base reflecting the recent foundation of the city (Figure 3.10). As before, the water, sewerage and telephone services show barely any progress in coverage between 1989 and 1994. However between 1994 and

\footnotetext{
${ }^{8}$ The three surveys used were Encuesta Integrada de Hogares $(1989,1994)$ and Encuesta Continua de Hogares (1999). Together these make it posible to build-up a picture of coverage before, during and after the reform process. The coverage rates emerging from the household survey data are broadly consistent with those derived from utility connection data; however, they do not always coincide. This is for a variety of reasons, including: differences in the definition of what constitutes a connection; the presence of illegal connections in the survey data; and sampling error. In the case of telephone services, the 1989 survey did not include an explicit question about telephone connections, hence reported expenditure on telephone services was taken as evidence of access to a telephone.
}

${ }^{9}$ National quintiles are used in this analysis. The implication is that the first quintile represents the same absolute income level both in La Paz and El Alto. 
1999, water coverage increases by 35 percentage points, sewerage by 15 percentage points, and (fixed plus cellular) telephone coverage quadruples from $2 \%$ to $8 \%$. Unfortunately, the household survey data does not distinguish between fixed and cellular telephones. However, given that the coverage of fixed line telephones in El Alto was found to be static over this period (Figure 3.7), it can be inferred that these gains are largely attributable to the diffusion of cellular telephony. The expansion of electricity coverage, on the other hand, continues to increase at the same rate of about 2 percentage points each year, before and after the reform.

Figure 3.10: Evolution of coverage for poorest quintile in El Alto

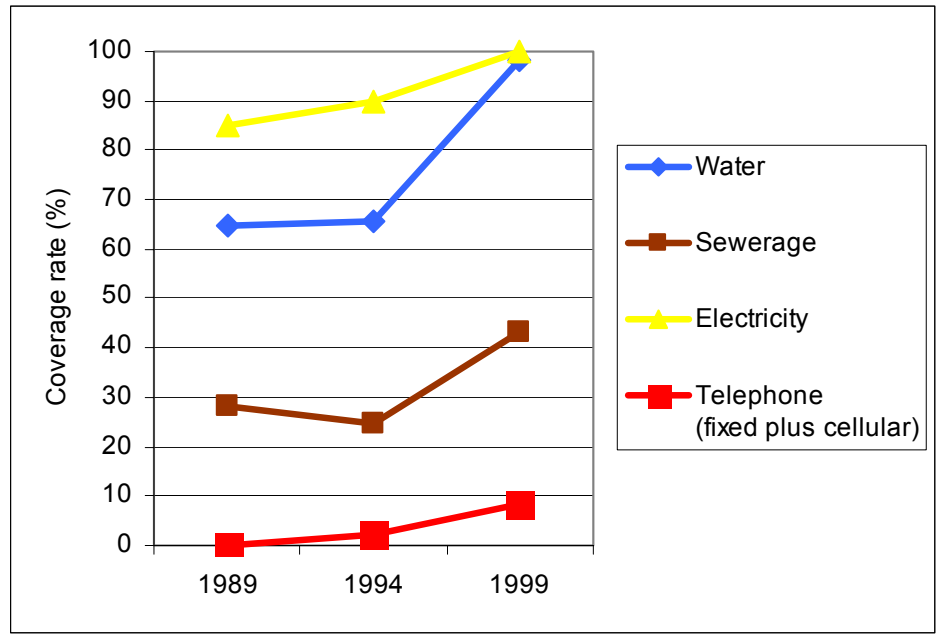

Sources: Encuesta Integrada de Hogares (1989, 1994); Encuesta Continua de Hogares (1999)

A more indirect way of looking at the distribution of new connections between rich and poor households is to take geographical location as a proxy for poverty. The 1992 Census, which adopts a methodology of unsatisfied basic needs for the measurement of poverty, finds that by far the highest poverty rates are to be found in El Alto, the next highest in the 'laderas' of La Paz and the northern suburbs, and the lowest poverty rates in the central and southern suburbs of La Paz (Figure 3.11). In terms of absolute numbers, only a tiny fraction of the poor are to be found in the affluent central and southern neighborhoods. The remainder are evenly divided between El Alto and the northern neighborhoods and 'laderas' or La Paz (Figure 3.12).

Figure 3.11: Poverty rates by geographical area

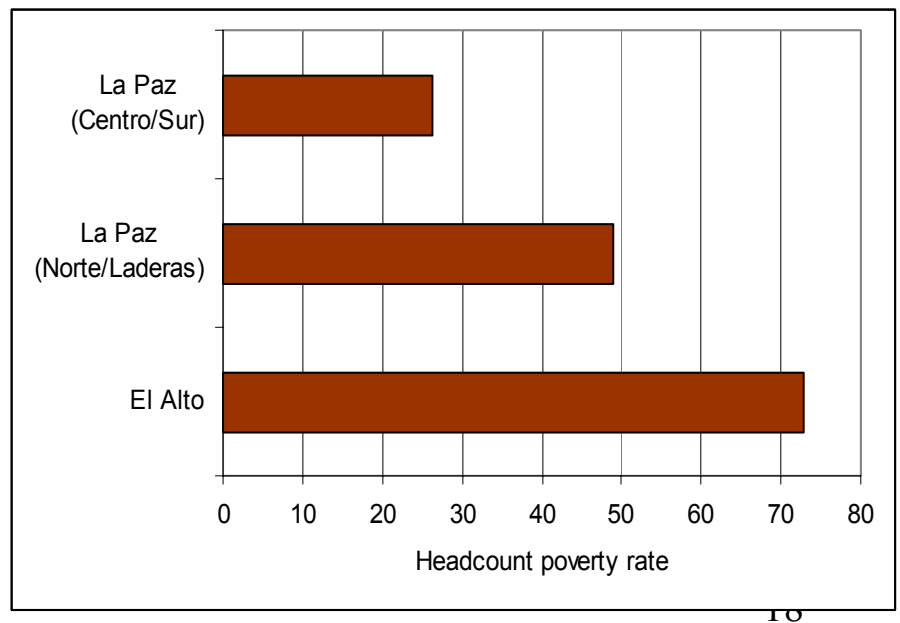


"The census measures poverty on the basis of 'unsatisfied basic needs'.

Source: Census, 1992

\section{Figure 3.12 : Geographical distribution of poor}

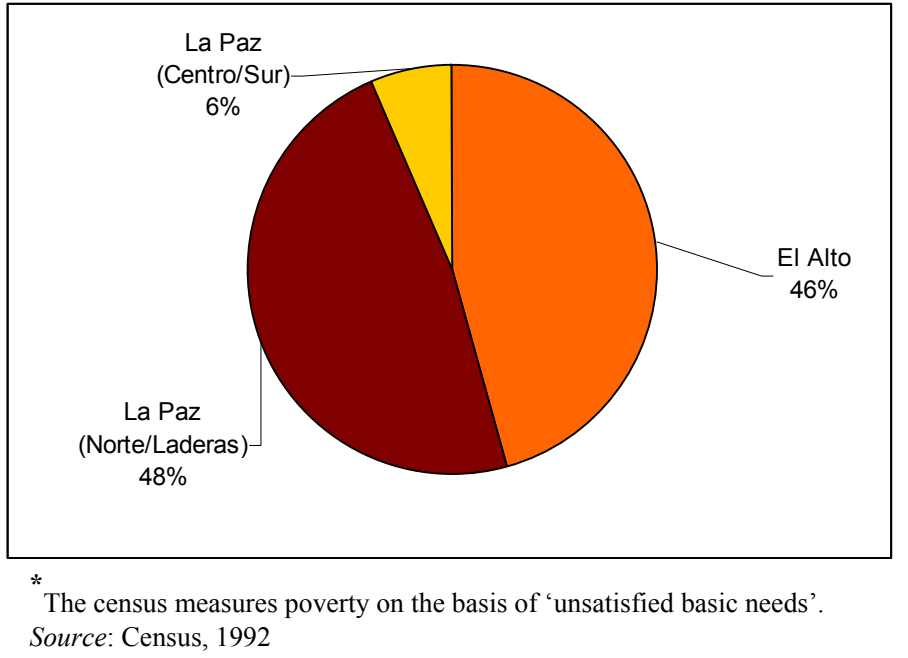

It is therefore of relevance to examine how the new connections made during this period were distributed between richer and poorer neigborhoods (Figure 3.13). While the fact that a new connection takes place in a poorer area is certainly no guarantee that it went to a poor household, the probability that it did so is at least substantially higher than in a more affluent area-indeed at least three times as high in El Alto as in the central or southern neighborhoods of La Paz.

\section{Figure 3.13: Geographical distribution of new connections}

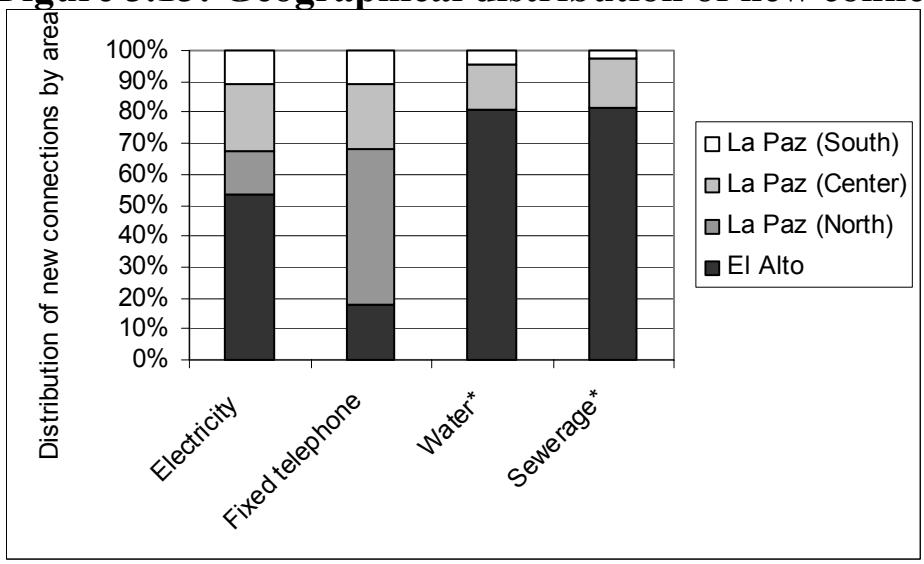

Sources: Electropaz, AISA and COTEL, 2000

The analysis reveals that in the case of water and sewerage, more than $80 \%$ of new connections were made in the poorest areas: El Alto and the northern 'laderas' of La Paz. While this undoubtedly reflects the contractual obligations on AISA, it is important to 
note that most of the unserved demand is - in any case - concentrated in these areas of the city, so that one would expect to see new connections to follow this pattern ${ }^{10}$. (Indeed, $60 \%$ of unserved demand for water and $90 \%$ of unserved demand for sewerage was in El Alto.) In electricity, 55\% of new connections went to El Alto, which is relatively low considering that $95 \%$ of the unserved demand for the service is in El Alto. While in the case of telephones only $20 \%$ of new connections went to homes in El Alto, even though $60 \%$ of the unserved demand is in El Alto.

This suggests that - notwithstanding the concentration of unserved demand in low income areas - the geographical obligations applied in the case of water and sewerage did have a significant effect in increasing the proportion of new connections that went to households in poor areas such as El Alto and the 'laderas'; probably by around $25 \%{ }^{11}$.

Overall picture. The results indicate that the reforms led to substantial increases in the rate of new connections for water and sewerage services, and much more so for cellular telephony. As a result, coverage of water and electricity services has come close to universal, while coverage of sewerage and telephony services has significantly improved. There is considerable evidence that these improvements in access have benefited the poor. First, the coverage rates of water and electricity in La Paz and El Alto, and the coverage of sewerage in La Paz, are higher than the percentage of non-poor households in these cities. This implies that poor households must have benefited from the increase $\mathrm{s}$ in coverage experienced following the reform. Second, more than two thirds of new connections were made in poorer areas such as El Alto and the 'laderas' of La Paz. Third, there were substantial increases in the access rates of the lowest quintile to all services between 1994-99, whereas general coverage increases between 1989-94 had largely failed to reach this segment of the population.

Finally, it is interesting to reflect on the differing mechanisms through which these coverage improvements were achieved across sectors. In the case of water and sewerage, the strategy of mandating access improvements in poorer neighborhoods has been very effective, with overall coverage gains in the sewerage service exceeding those found elsewhere in Bolivia and coverage gains for water and sewerage among poorer households outstripping those of the other services. In the case of fixed telephony, the reduction of the connection charge appears to have had a substantial impact on access in the middle income neighborhoods or northern La Paz. However, the most dramatic improvements were those resulting from the advent of competition in cellular telephony.

\footnotetext{
${ }^{10}$ The comparison between water and sewerage and the other services is complicated by differences in the definition of geographical areas. For the water and sewerage service, the northern suburbs of La Paz are effectively divided between the El Alto region (which incorporates the 'laderas') and the central region of La Paz (which incorporates some of the lower lying northern suburbs).

${ }^{11}$ The figure of $25 \%$ is arrived at in the following way. For water and sewerage, where there were geographical obligations about $80 \%$ of new connections went to El Alto plus the 'laderas' of La Paz. For electricity and fixed telephone, where there was no geographical obligation about $65 \%$ of new connections went to El Alto plus the 'laderas' of La Paz. Hence, the water and sewerage sector achieved a $25 \%$ higher $(=80 \% / 65 \%)$ allocation of new connections to poorer neighborhoods relative to electricity.
} 
There is indirect evidence to suggest that the benefits of these changes have been felt even by the poorest households.

\section{Affordability of Service}

In all three sectors, the reform process led to changes in the average level of tariffs and the tariff structures faced by utility customers (Table 4.1).

Table 4.1: Cross-sectoral overview of tariff reforms

\begin{tabular}{|c|c|c|c|}
\hline & Electricity & Telecommunications & Water and Sewerage \\
\hline $\begin{array}{l}\text { Real tariff } \\
\text { increases }\end{array}$ & $\begin{array}{l}\text { Average tariffs have risen } \\
\text { gradually by } 21 \% \text { since } \\
\text { reform in } 1996 . \\
\text { However, the average annual } \\
\text { growth rate of tariffs fell } \\
\text { slightly from } 7.3 \% \text { in the } \\
\text { period } 1992-95 \text { to } 6.5 \% \text { in the } \\
\text { period } 1996-99 .\end{array}$ & $\begin{array}{l}\text { Following reform, the cost of local } \\
\text { charges remained broadly constant. } \\
\text { Long distance and international } \\
\text { tariffs increased significantly } \\
\text { between } 1996 / 98 \text {, but then began to } \\
\text { decline. Following market } \\
\text { liberalization in December } 2001 \text {, } \\
\text { tariffs fell by } 67 \% \text { relative to levels } \\
\text { prevailing in } 1996 \text {. }\end{array}$ & $\begin{array}{l}\text { Average tariffs rose instantaneously by } \\
20 \% \text { at the time of reform, and have } \\
\text { subsequently been indexed to the dollar. }\end{array}$ \\
\hline $\begin{array}{l}\text { Changes in tariff } \\
\text { structure }\end{array}$ & $\begin{array}{l}\text { Only very minor adjustments } \\
\text { to the increasing block tariff } \\
\text { structure were made. } \\
\text { There continue to be four } \\
\text { categories of domestic } \\
\text { customer, with standing } \\
\text { charges of } \$ 3-\$ 10 \\
\text { differentiated according to the } \\
\text { quality of service received in } \\
\text { terms of voltage level. }\end{array}$ & $\begin{array}{l}\text { Prior to reform a fixed monthly } \\
\text { charge of } \$ 3 \text { was levied for local } \\
\text { service and all calls were } \\
\text { subsequently 'free'. } \\
\text { Following reform, a number of } \\
\text { calling plans are available, }\end{array}$ & $\begin{array}{l}\text { Radical simplification of the tariff } \\
\text { structure from } 150 \text { categories of users to } \\
\text { just three (domestic, commercial and } \\
\text { industrial) })^{12} \text {. } \\
\text { Prior to reform a fixed monthly charge } \\
\text { of } \$ 1-\$ 2 \text { was levied with an entitlement } \\
\text { to a 'free' block of } 10 \text { cubic meters of } \\
\text { consumption. This fixed charge was } \\
\text { eliminated and a unit charge is now } \\
\text { levied on all consumption. }\end{array}$ \\
\hline
\end{tabular}

Figure 4.1: Evolution of average tariff level

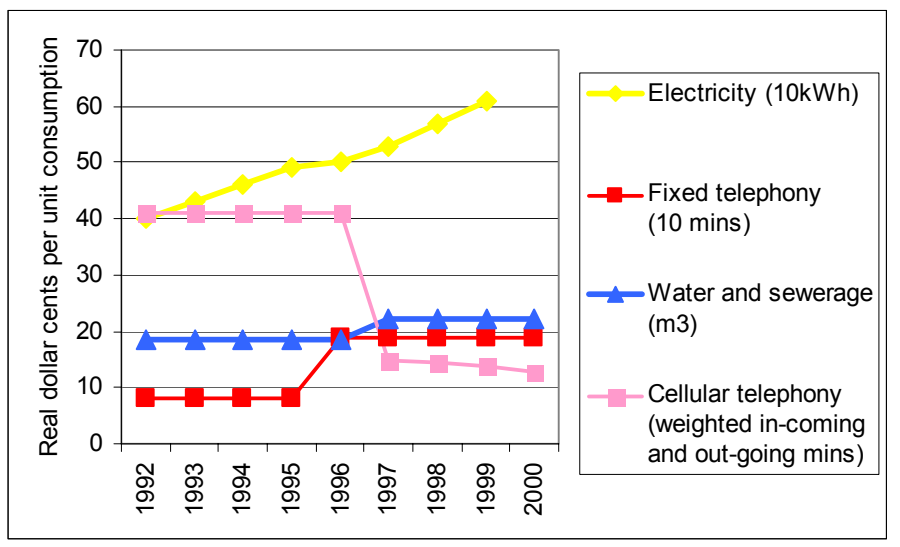

Source: Barja and Urquiola, 2001.

${ }^{12}$ The previous tariff structure for water and sewerage had 135 categories for unmeasured customers and 15 for measured customers. The categories were based on property values, connection diameters, and geographic location. The complexity of the tariff structure often rendered customer classifications somewhat arbitrary. 
Electricity. The average tariff for electricity has risen by around $20 \%$ in real terms since the reform (Figure 4.1), continuing a trend of gradual price increase throughout the 1990s. Although Electropaz's tariffs have risen more steeply during the course of the 1990s than those in Cochabamba and Santa Cruz, they are currently at very similar levels to those charged in Bolivia's other two major cities (Barja and Urquiola, 2001).

While, the electricity tariff structure barely changed as a result of the reform (Figure 4.2). Residential customers continue to be classified into four groups according to the quality of service they receive, in particular the level of voltage and the type of transmission (monofasic or trifasic). Higher quality of service is reflected in a greater fixed charge ranging from $\$ 3-\$ 10$. However, all types of customers face similar unit charges for actual use of electricity, following a rising block schedule.

Figure 4.2: Electricity tariff structure

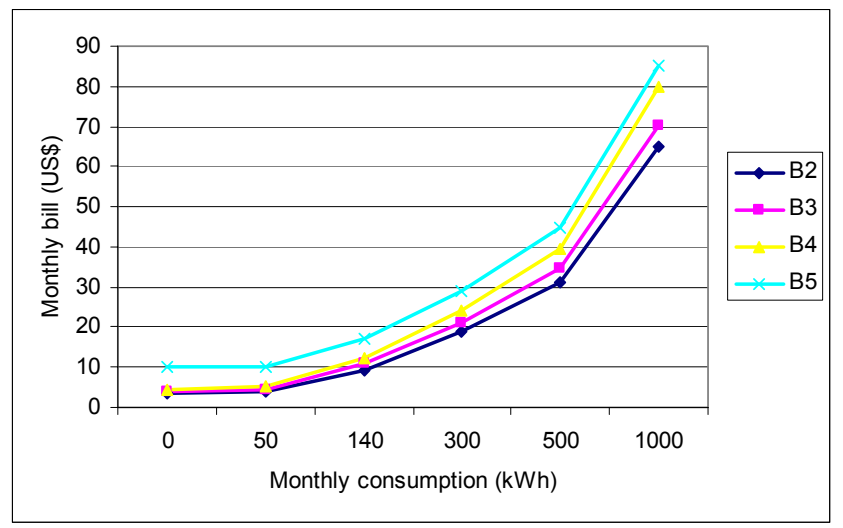

Source: Electropaz, 2000

Water and sewerage. The average tariff for water and sewerage has risen by around $20 \%$ in real terms since the reform (Figure 4.1). This took the form of a step change brought in immediately prior to the reform in order to ensure the financial sustainability of the concession (Uzin, 1996). This is modest when compared to increases of $50 \%$ between 1994-97 in Cochabamba, and 75\% between 1995-99 in Santa Cruz (Barja and Urquiola, 2001). Indeed, water tariffs in La Paz and El Alto are currently similar to those charged in Cochabamba and barely a third of those charged in Santa Cruz.

The principal reform of the tariff structure for water was a radical simplification from 150 different tariff structures (which differentiated-in a far from transparent manner - between customers according to geographic area, property value, diameter of connection and socioeconomic level) to a single tariff structure for domestic customers. Furthermore, the reform eliminated the fixed charge which corresponded to a minimum consumption block of 10 cubic meters per month. This policy change was based on the desire to eliminate an implicit cross-subsidy between large and small consumers. The reason is that average measured consumption for customers falling below this threshold of 10 cubic meters per month was only 5.2 cubic meters, so that these small consumers - many of them in low income neighborhoods - were being forced to pay for 
water that they did not consume and hence effectively incurring a higher unit charge per cubic meter than larger consumers (Uzin, 1996).

Consequently, in spite of the overall average tariff increase of $20 \%$, the new tariff structure generates lower bills for those consuming less than around 7 cubic meters per month (Figure 4.3). This is close to the average consumption for households in El Alto, but less than a third of the average for households in La Paz.

\section{Figure 4.3: Changes in tariff structure for water and sewerage*}

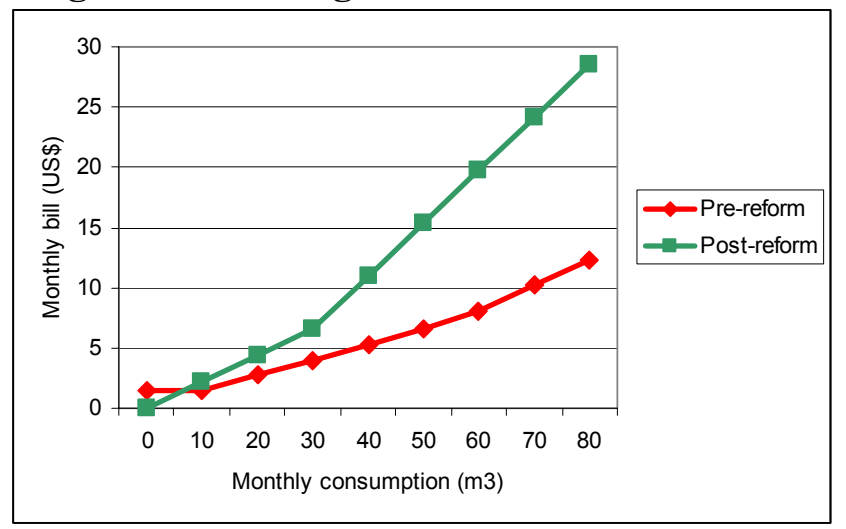

Source: Uzin, 1996

The La Paz peri-urban domestic tariff is taken as an illustration of the pre-reform tariff structure.

Finally, there does not seem to be any evidence that households have had difficulties in paying the post-reform water charges. Indeed, the data show that revenue collection in both La Paz and El Alto improved by around 15\% following the reform, and now stands at around $94 \%$ in both cities. The percentage of customers disconnected for non-payment has remained stable at around 3.6\% in La Paz, and has fallen in El Alto to the much lower rate of $1.5 \%$ (Table 4.2 ).

Table 4.2: Revenue collection statistics for water and sewerage

\begin{tabular}{|l|c|c|c|c|}
\hline$(\%)$ & \multicolumn{3}{|c|}{ La Paz } & \multicolumn{3}{c|}{ El Alto } \\
& 1997 & 2000 & 1997 & 2000 \\
\hline & & & & \\
Revenue collection rate (within 6 months) & 81.0 & 94.0 & 78.0 & 93.0 \\
Percentage of customers disconnected for non-payment & 3.5 & 3.7 & 2.5 & 1.5 \\
\hline
\end{tabular}

Source: AISA, 2000

Telephones. The average domestic tariff for fixed telephony doubled from $\$ 0.01$ to $\$ 0.02$ per minute. At the same time the tariff structure was changed from a flat rate monthly charge of $\$ 3.00$ to a fixed charge of either $\$ 0.83$ or $\$ 1.74$ (depending on the calling plan), with an entitlement to a block of 100 or 200 minutes per month respectively. Hence, the implicit price per minute in this first block is just under $\$ 0.01$. However, consumption beyond this attracts a tariff of $\$ 0.03$ per minute. The implication is that the average COTEL domestic customer-who makes 356 minutes of local calls each month - has seen bills increase by more than $200 \%$ following the reform. However, any customer making less than 242 minutes of local calls each month is better-off under the new tariff structure (Figure 4.4). 
Although ENTEL's long distance charges increased by 50\% between 1996/98, they began to decline gradually towards the end of the exclusivity period. Following market liberalization in December 2000, they fell steeply reaching a third of levels prevailing in 1996 within a few months of the advent of competition.

In contrast, liberalization of the cellular market led to substantial tariff reductions from 1997 (Barja and Urquiola, 2001). As a result of aggressive competition between Telecel and ENTEL Movil, consumers benefited from a number of tariff reductions. First, the fixed monthly charge of US\$30 (without any 'free' minutes) was cut back. Second, the practice of charging $\$ 0.41$ per minute for both incoming and outgoing calls was replaced by a 'calling party pays' tariff of $\$ 0.45$ per minute for outgoing calls only. Taking a weighed average of in-coming and out-going calls ${ }^{13}$, this implies that the cost of using a cellular telephone fell by $68 \%$ as a result of this change, and subsequent reductions in the price of out-going calls from $\$ 0.45$ to $\$ 0.39$ per minute. Third, the option of prepaid cellular telephones was introduced with card denominations as low as $\$ 5$, making the service more attractive to small consumers. Although matching all of these changes introduced by ENTEL Movil, Telecel also made formal complaints to the regulator that ENTEL was engaging in anti-competitive practices by cross-subsidizing between its cellular and long distance businesses.

\section{Figure 4.4: Changes in tariff structure for fixed telephony}

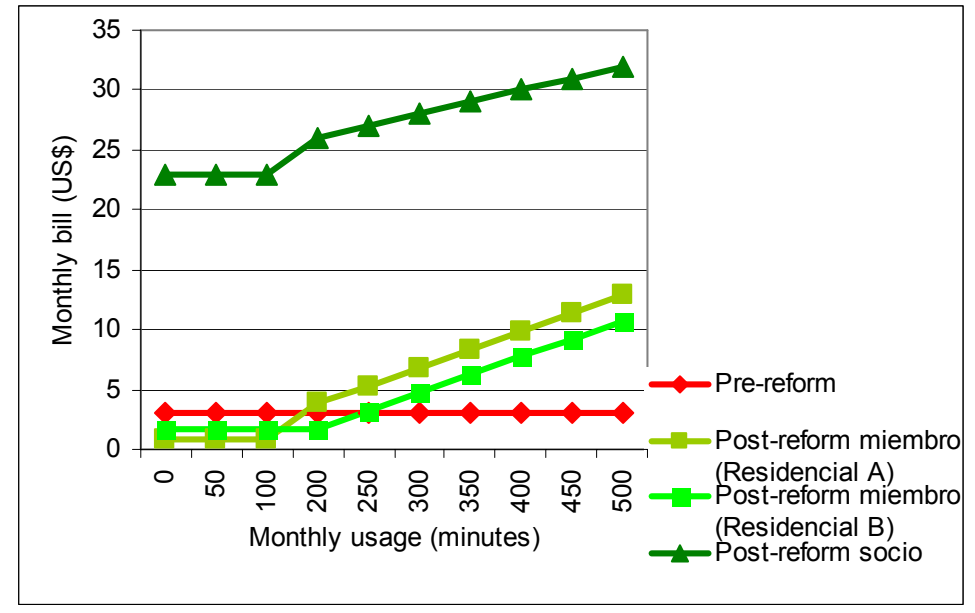

Source: COTEL, 2000.

Finally, it is interesting to compare the relative attractiveness of fixed line versus cellular telephony for lower income customers. As noted above, in 1996 COTEL made it possible for customers to obtain a connection to fixed line service much more cheaply than before, by becoming 'socios' (associates) as opposed to members of the cooperative. However, customers taking this route face high fixed charges of \$23 per month. Comparing these rates with those available for cellular service suggests that this type of fixed line connection is only attractive to those making more than about 90 minutes of local

\footnotetext{
${ }^{13}$ SITTEL informs that on average two thirds of traffic to cellular telephones in in-coming and one third is out-going. These weights have been applied to the corresponding tariffs to come-up with the average value presented above.
} 
telephone calls per month, since otherwise it is substantially more attractive to opt for a prepaid cellular telephone or even a basic cellular calling plan (Figure 4.5). This comparison illustrates how COTEL's tariff structure has probably had the effect of displacing demand from the fixed to the cellular market.

\section{Figure 4.5: Relative cost of fixed versus cellular telephony}

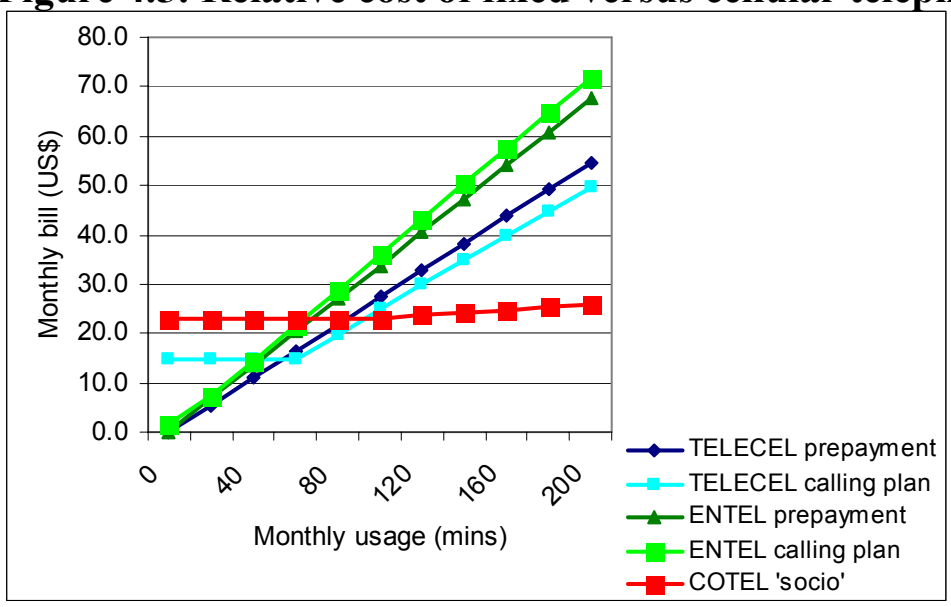

Overall picture. The analysis shows that the reform led to significant tariff increases of $50 \%$ for fixed line telephony, and $20 \%$ for water and electricity services. Both long distance and cellular telephony charges, on the other hand, have fallen substantially. At the same time, the water and telephony sectors have introduced significant changes in tariff structures whose overall effect is to favor smaller customers over larger customers. Indeed, when the net effect of changes in the tariff level and tariff structure are taken into account, small customers actually face lower charges than before the reform. To the extent that smaller customers are also poorer customers, these changes may have benefited the poor; however unfortunately there is not adequate data to test this hypothesis. Finally, owing to COTEL's policy of levying high fixed charges on customers who are not members of the cooperative, cellular telephony is currently a much more attractive option for low income low usage households who are not able to raise the $\$ 1,500$ cooperative membership fee.

\section{Customer Satisfaction}

An important aspect of the reforms, affecting all three of the services, was the introduction of legally binding quality of service parameters with associated fines for non-compliance. There is evidence of some improvements in quality of service since the reforms. In the water sector, for example, the percentage of clients suffering from poor pressure or intermittent service fell from 34\% in 1997 to less than 1\% in the year 2000 . However the percentage of samples failing water quality standards has remained broadly constant at around $27 \%$. 
As part of the reform process, a customer complaints system (ODECO) was established to allow users to express dissatisfaction with the service and to seek redress from the utility. First round complaints can be made to the customer service center operated by each of the utility companies. Moreover, if the dispute is not adequately resolved, the customer has the option of raising a second round complaint with the regulatory agency (SIRESE). Most recently, the Superintendencia de Electricidad has introduced a virtual complaints system with a view to extending its reach throughout the country. Using the 'virtual ODECO' terminals stationed in major urban centers, use ISDN lines to provide an interactive multi-media link to the Superintendency's offices in La Paz including the possibility of having a video-conference consultation with a customer service representative in La Paz.

It is interesting to ask to what extent this customer complaint system succeeds in reaching customers from lower income groups. While it is not possible to answer this question directly, some indirect inferences can be made by comparing customer complaints statistics across the cities of $\mathrm{La} \mathrm{Paz}$ and El Alto (Table 5.1). The results show that (relative to their total numbers) consumers in La Paz are very much more likely to lodge complaint as consumers in El Alto. In the case of complaints made directly to the utility company, the differential is a factor of three in the case of water and sewerage. In the case of complaints made directly to the Superintendency, the differential is around [add water], a factor of 3 for electricity, and 6 for telecommunications. The data for telecommunications show that less than $6 \%$ of first round complaints, resulted in a second round complaint to the Superintendency.

Table 5.1: Customer complaints, 1997-2000

\begin{tabular}{|c|c|c|c|c|c|c|}
\hline & \multicolumn{2}{|c|}{ Electricity } & \multicolumn{2}{|c|}{ Telecommunications } & \multicolumn{2}{|c|}{ Water and Sewerage } \\
\hline & $\mathrm{LaPaz}$ & El Alto & $\mathrm{La} \mathrm{Paz}$ & El Alto & $\mathrm{LaPaz}$ & El Alto \\
\hline $\begin{array}{l}\text { First round complaints } \\
\text { No. of complaints } \\
\text { Complaints per ' } 000 \text { customers }\end{array}$ & - & - & \multicolumn{2}{|c|}{6,773} & $\begin{array}{c}14,317 \\
92.0\end{array}$ & $\begin{array}{c}5,784 \\
36.5\end{array}$ \\
\hline $\begin{array}{l}\text { Second round complaints } \\
\text { No. of complaints } \\
\text { Complaints per ' } 000 \text { customers } \\
\% \text { of first round complaints }\end{array}$ & $\begin{array}{c}472 \\
2.9\end{array}$ & $\begin{array}{l}99 \\
1.0\end{array}$ & $\begin{array}{c}375 \\
2.9\end{array}$ & $\begin{array}{c}12 \\
0.5\end{array}$ & - & - \\
\hline
\end{tabular}

\section{Conclusions}

The broad picture that emerges from the analysis of the impact of utility service reforms in La Paz and El Alto is one of expanding access in the context of rising prices and improved accountability for quality of service. There is significant evidence that low income households benefited considerably from the growth of coverage. The cost of both long distance and cellular telephony fell by almost 70\%. Tariffs for all other services increased significantly. Nonetheless, owing to concomitant reforms in tariff structure, many small consumers would actually have experienced falling bills.

The effects of the reform differed significantly across sectors, reflecting different adjustments to the regulatory framework. The impact appears to have been least 
significant in the electricity sector, where the concession contract did not incorporate any major changes with respect to tariff policies or service obligations. In water, and particularly sewerage, substantial gains in coverage were made largely as a result of mandatory connection targets in poorer neighborhoods. However, the greatest impact both in terms of expanding access and falling prices came as a result of licensing a second cellular operator. This impact was amplified by the tariff policies of the fixed line operator COTEL, which appear to have served to displace demand from the fixed to the cellular market.

The pattern of change also differed across the two cities. In the city of La Paz, by far the largest gains in access were in telecommunications. While in the city of El Alto, substantial progress was made in water and sewerage coverage. Moreover telephone penetration almost tripled largely as a result of growth in cellular lines.

The analysis also suggests that the impact on the poor could have been greater if certain pro-poor policies adopted in some sectors had been applied across the board. For example, some of the pro-poor policies in the water and sewerage sector-in particular geographical connection targets and the possibility of paying back connection charges in installments - would have been very beneficial for the electricity sector. While the benefits of introducing a lower connection charge for non-members of the telephone cooperative, were largely cancelled out by the very high fixed charges associated with these kind of accounts.

\section{Bibliography}

Barja, G. and Urquiola, M. (2001) Capitalization, Regulation and the Poor: Access to Basic Services in Bolivia, United Nations University and World Institute for Development Economic Research.

Estache, A., Foster, V. and Wodon, Q. (forthcoming) Utility Sector Reform and the Poor: Learning from Latin America's Experience, Latin America and Caribbean Region Regional Studies Program and World Bank Institute Studies in Development, The World Bank Group, Washington DC.

Foster, V. (forthcoming) Economic and Financial Evaluation of the El Alto Pilot Project: Condominial Water and Sewerage Systems, Water and Sanitation Program, The World Bank Group and United Nations Development Program, Washington DC.

Komives, K. (1999) Designing Pro-Poor Water and Sewer Concessions: Early Lessons from the Aguas del Illimani Concession in Bolivia, Mimeo, Finance, Private Sector and Infrastructure Division, The World Bank Group, Washington DC.

Komives, K. and Brook Cowen, P.J. (1999) Expanding Water and Sanitation Services to Low Income Households: The Case of the La Paz-El Alto Concession, Viewpoint Note 
No. 178, Finance, Private Sector and Infrastructure Network, The World Bank Group, Washington DC.

Morales, R., Azero, R., Szmukler, A. And Mollinedo, F. (1995) Desarrollo Humano en las Montañas, Informe del Desarrollo Humano de la Ciudad de La Paz, Gobierno Municipal de la Ciudad de La Paz y Programa de las Naciones Unidas para el Desarrollo.

Navajas, S., Schreiner, M., Meyer, R.L., Gonzalez-Vega, C. and Rodríguez-Meza, J. (2000) 'Microcredit and the poorest of the poor: theory and evidence from Bolivia', World Development, Vol. 28, No. 2, pp.333-346.

Uzin, L.G. (1996) Estudio Tarifario SAMAPA, Mimeo, Consultant's Report to SAMAPA, La Paz.

World Bank (2001) Bolivia: Poverty Diagnostic 2000, Prepared jointly by Instituto Nacional de Estadistica, Unidad de Analisis de Politicas Economicas and The World Bank Group, Washington DC. 
Annex

Table A1: Cross-sectoral view of affordability of new connections

\begin{tabular}{|c|c|c|c|c|c|c|c|}
\hline & \multirow[t]{2}{*}{ Electricity } & \multicolumn{2}{|c|}{ Telecommunications } & \multicolumn{2}{|c|}{ Water } & \multicolumn{2}{|c|}{ Sewerage } \\
\hline & & $\begin{array}{l}\text { Fixed } \\
\text { line }^{v}\end{array}$ & $\begin{array}{l}\text { Mobile } \\
\text { line` }\end{array}$ & Regular & Condominial* & Regular & Condominial $^{*}$ \\
\hline $\begin{array}{l}\text { Affordability of connection } \\
\text { - Connection charges (\$) } \\
\text { - One time charge } \\
\text { - Minimum monthly charge } \\
\text { - Multiples of minimum wage (\#) } \\
\text { - One time charge } \\
\text { - Minimum monthly installment }\end{array}$ & $\begin{array}{l}150 \\
-\end{array}$ & $\begin{array}{c}800 \\
27 \\
16.0 \\
0.5\end{array}$ & $\begin{array}{c}60-160 \\
-\end{array}$ & $\begin{array}{c}155 \\
7 \\
\\
3.1 \\
0.1\end{array}$ & $\begin{array}{c}136 \\
6 \\
\\
2.7 \\
0.1\end{array}$ & $\begin{array}{c}180 \\
8 \\
\\
3.6 \\
0.2\end{array}$ & $\begin{array}{c}100 \\
4 \\
\\
2.0 \\
0.1\end{array}$ \\
\hline
\end{tabular}

- This is the minimum charge and corresponds to a non-member's account. Those wishing to become members of the cooperative must pay a connection charge that at $\$ 1,500$ is almost twice as high. However, this entitles to a significant reduction in call charges.

- This is based on the cost of $\$ 50-\$ 150$ for a cellular telephone plus a typical $\$ 10$ activation charge.

*'Condominial' water and sewerage connections represent a lower cost design and involve labor contributions from the household. Sources: Electropaz, COTEL and AISA.

WB159424

L: $\mid$ Bolivia $\backslash$ Poverty $\mid$ PovertyChapter.doc

April 9, 2001 9:14 AM 